\title{
Endnotes
}

Introduction

1 Ben-Ami Shillony, The Successful Outsiders: The Jews and the Japanese (Rutland, VT: Tuttle, 1991).

2 Rotem Kowner's work includes the following: On Ignorance, Respect and Suspicion: Current Japanese Attitude towards Jews (Jerusalem: Vidal Sassoon Center, 1997); " "Tokyo Recognizes Auschwitz: The Rise and Fall of Holocaust Denial in Japan 1989-1999," Journal of Genocide Studies 3 (2001): 257-272; "The Protocols in a Land Without Jews: A Reconsideration," Anti-Semitism International 3-4 (2006): 66-77; and "On Symbolic Anti-Semitism: Motives for the Success of the Protocols in Japan and its Consequences," in Posen Papers in Contemporary Anti-Semitism (Jerusalem: Vidal Sassoon Center, 2006); and "The Japanese Internment of Jews in Wartime Indonesia and its Causes," Indonesia and Malay World 38 (2010): 349-371. He is also the editor of Rethinking the Russo-Japanese War: Centennial Perspectives (Leiden: Brill, 2007).

Among Ben-Ami Shillony's pertinent works are: "Japan and Israel: The Relationship that Withstood Pressure," Middle East Review 18 (1985); The Successful Outsiders: The Jews and the Japanese (Rutland: Tuttle, 1992); "Auschwitz and Hiroshima: What We the Jews and the Japanese do for World Peace," Bulletin of the International House of Japan 27 (2007): 1-18; "The Flourishing Demon: Japan in the Role of the Jews," in Robert Wistrich, ed., Demonizing the Other: Anti-Semitism, Racism and Xenophobia (Amsterdam: Harwood Academic, 1999); "Jews Against Japanese or Jews with Japanese in the War, Jewish Response to the War," in Rotem Kowner, ed., Rethinking the Russo-Japanese War, Centennial Perspectives, 393-400; "Hatred of the Jews without Jews: The Anti-Semitic Ideology of Japan during World War II," Zion 46 (1981): 125-145; Japanese Views of Jews and Judaism (Jerusalem: Hartman Center for Contemporary Judaism, The Hebrew University of Jerusalem, and the Shazar Center, 1993); and Japan from a Personal Perspective (Tel Aviv: Schocken, 2011).

3 Among works by German scholars on Japan and the Jews see Martin Kaneko, Die Judenpolitik der Japanischen Kriegsregirierubg (Berlin: Metropol Verlag, 2008); Gerhard Krebs, Japan's Deutschland Politik 1935-1941 (Hamburg: 1984); ibid, "Die Juden und der Ferne Osten. Ein Literaturbericht," Nachrichten der 
Gesselschaft fur Natur und Volkerkunde Ostasiens 175-176 (2004): 229-270; Francoise Kreissler, “Japan's Judenpolitik 1931-1945," in Gerhard Krebs and Bernd Martin, eds., Fornierung und Fall der Achse Berlin-Tokyo (Munich: Lidicum Verlag, 1984), 187-210; Bernd Martin, Deutschland und Japan in Zweiten Weltkrieg: Von Angriff auf Pearl Harbor bis Deutschen Kapitulation (Gottingen: Museterschmidt Verlag, 1969); Heinz Maul, Why did Japan not Persecute the Jews? (Tokyo: Fuyo Shobo Shippan, 2004); Birgit Pansa, Juden unter Japanischer Exilfahrungen der Sonderefal Karl Lowith(Munich: Lidicum, 1999).

For a list of major works dealing with the Shanghai Jewish Community, see note 63.

5 See, for example, Ikeda Afikumi, "Japan's Perception of Jews and Israel," Forum 59 (1986): 73-84; Inuzuka Kiyoko Yudaya Mondai to Nihon no Kosaku: Kaigun Znuzuka Kikan no Kiroku (The Jewish Question and Japan's Strategy: The Records of the Navy and Inuzuka) (Tokyo: Nihon Kogyyo Shinbunsha), 1982; Kohno Tetsu, "Debates on the Jewish Question in Japan," Bulletin of the Faculty of Liberal Arts Hosei University, Tokyo (1983): 1-33; ibid, "The Jewish Question in Japan,” Jewish Journal of Sociology 29 (1987): 37-54; Kobayashi Masayuki, Yudayajin (The Jews) (Tokyo: 1977); Abraham Kotsuji, From Tokyo to Jerusalem (New York: Geis, 1964); and Kubata Taro, "Sugihara Chiune, dei Juden retter aus Japan," Zeitschrift fur Geschischts Wissenschaft 55 (2007): 645-600.

One of the more prolific Japanese scholars on Jewish issues is Maruyama Naoki. Among his works are "Japan's Response to the Zionist Movement in the 1920's," Bulletin of the Graduate School of International Relations, Tokyo, 2 (1984): 27-40; "The Shanghai Zionist Association and the International politics of East Asia until 1936," in Jonathan Goldstein, ed., The Jews of China: Historical and Comparative Perspectives (Armonk, NY: Sharpe, 1999), 251266; "Facing a Dilemma: Japan's Jewish Policy in the late 1930's," in Guy Podoler, ed., War and Militarism in Modern Japan: Issues of History and Identity (Folkestone: Global Oriental, 2009), 22-38; “Japan's Anti-Semitism and U.S.-Japan Relations," paper presented at the Southern Japan Seminar, Atlanta, April 23 1994; and Taiheiyo senso to shanhai Yudaya nanmin (The Pacific war and the Jewish Refugees in Shanghai) (Tokyo: Hosei Daigaku, 2005). Other books of interest on this topic include Miyazawa Masanori, Yudayajin Ronko (Tokyo: 1973); Ryuuta Mizuuchi, "Sugihara Visas, Unknown Facts and Hidden Intentions," paper presented in Jerusalem, April 13, 1987; Sakai Shogun,. Yudaya Minzoku no dai-imbo (Tokyo: Naigai Shobo, 1924); Sato Izumi, "History of the Kobe Jewish Community," paper presented at the $96^{\text {th }}$ Annual Meeting of the American Anthropological Association, Washington 
DC, November 21, 1997; Sekine Maho, Nihon senryoko no Shanghai Yudayajin Getto (Shangahi Ghetto under the Japanese Occupation) (Kyoto: Showado, 2010); Sugita Rokuichi, Higashi Ajia e kita Yudayajin (Tokyo: 1967); Teshima Ikuro, The Ancient Jewish Diaspora in Japan: The Tribe of Haka, Their religious and Cultural Influences (Tokyo: Tokyo Bible Seminary, 1973); Yamamuro Shinichi, Manchuria Under Japanese Domination (Philadelphia: University of Pennsylvania Press, 2006); and Yasue Norihiro, Kakumei undo wo abaku: Yudaya no chi wo fumite (Unmasking a Revolutionary Movement: Setting foot on Jewish Soil) (Tokyo: Shokasha, 1931).

6 Shillony, The Successful Outsiders.

\section{Chapter 1: Early Jewish Settlers in Japan}

1. For the history of the Nagasaki community, see its entry in Encyclopaedia Judaica vol. 12, 758; Herman Dicker, Wanderers and Settlers in the Far East: A Century of Jewish Life in China and Japan (New York: Twaine, 1962); Reuven Kashani, Jewish Communities in the Far East (Jerusalem: 1982); And Ezra Yehezkel-Shaked, The Jews, Opium and the Kimono: The Story of the Jews in the Far East (Jerusalem: Rubin Press, 1997). On the Ginsburg family history see Jan Van Rij, Some of Them (Paris: L'Harmattan, 2011). See also The Nagasaki Kenritsu Survey of Foreign Households in the Nagasaki Concession, 1880-1900, and The Japan Directory: Listings of Foreign Companies and Individuals in Japan, 1879-1904.

2. There are a number of studies that include information on the Kadoories, among them Dennis Leventhal, The Jewish Community of Hong Kong (HongKong: Hong Kong Historical Society, 1988) and Mavis Meyer, From the Rivers of Babylon to the Whampoo: A Century of Sephardi JewishLife in Shanghai (Lanham, MD: University Press of America, 2003).

3. On the Sassoon family see Cecil Roth, The Sassoon Dynasty (London: Hale, 1941).

4. On the Yokohama community, see Herman Dicker, Wanderers and Settlers in the Far East (New York: Twayne, 1962); Reuven Kashani, The Jewish Community in Japan (Jerusalem: 1982); Israel Cohen, The Journal of a Jewish Traveler (London: Bodley Head, 1925); and Ezra Yehezkel-Shaked, The Jews, Opium and the Kimono (Jerusalem: Rubin Mass, 1997). See also The Jewish Community of Japan, $50^{\text {th }}$ Anniversary Yearbook (Tokyo: Jewish Community of Japan, 2004).

5. On Trumpeldor's imprisonment in Japan see my article "Jewish Nationalist in a Japanese Prison Camp," in Studies in Japanese Culture (Tokyo: Pen Club, 1973), 299-303. See also N. Benari, and A. Kenaani, Yosef Trumpeldor: 
His Deeds and Era (Tel Aviv: 1950); Y.S. Kanner, Yosef Trumpeldor: A Hero Among His People (Tel Aviv: Sinai, 1940); Shulamit Laskov, Trumpeldor: A Biography (Haifa: Shikmona, 1972); Menachem Poznanski, ed., The Life of Yosef Trumpeldor (Tel Aviv: Am Oved, 1945); and Pessach Lipovitsky, Yosef Trumpeldor: His Life, Personality and Deeds (Tel Aviv: Culture and Education, 1967).

6. For Jacob Schiff's involvement in financing Japan's war effort see: Cyrus Adler, Jacob Schiff: His Life and Letters (New York: Doubleday, 1928); Gary D. Best, "Financial Diplomacy: The Takahashi Korekiyo Mission 1904-1905," Asian Studies 12 (1974); ibid, "Financing a Foreign War: Jacob Schiff and Japan, 1904-05," American Jewish Historical Quarterly 61 (1972); ibid, “Jacob Schiff's Early Interest in Japan," American Jewish History 69 (1980): 355-359; A.J. Sherman, "German-Jewish Bankers in World Politics: The Financing of the Russo-Japanese War," Leo Baeck Institute Yearbook 1983: 59-73; Daniel Gutwein, "Realpolitik or Jewish Solidarity: Jacob Schiff's Financial Support for Japan Revisited," in Rotem Kowner, ed., Rethinking the Russo-Japanese War, 123-138; and Richard Smethurst, From Foot Soldier to Finance Minister: Takahashi Korekiyo, Japan's Keynes (Cambridge, MA: Harvard East Asia Center, 2007).

7. For a broad perspective of the Russo-Japanese War, see: Rotem Kowner, ed., Rethinking the Russo-Japanese War; K. Asakawa, The Russo-Conflict (London: Kennikat Press, 1970); Richard Connaughton, The War of the Rising Sun and the Tumbling Bear (London: Routledge, 1988); and John Stephen, The Russian Far East: A History (Stanford: Stanford University Press, 1994).

8. Chaim Weizmann, Trial and Error (London: 1948).

\section{Chapter 2: Jewish Settlers in Japan at the Beginning of the Twentieth Century}

1 See the documentary collection of the Hebrew Immigrant Aid Association in New York.

2 On the Kobe community, see Encyclopaedia Judaica 10, 118-1119; Herman Dicker, Wanderers and Settlers; Ezra Yehezkel-Shaked, The Jews, Opium, and the Kimono; Israel Cohen, The Journals of a Jewish Traveler; and Martin Kaneko, Yudayajin nanmin, 1940-1941(Kobe Jewish Refugees, 1940-1941) (Tokyo: Mizunowa Shuppan, 2003). See also Sato Izumi, "History of the Kobe Jewish Community," paper presented at the $96^{\text {th }}$ annual meeting of the American Anthropological Association, Washington, DC, Nov. 21, 1997, and Pamela Shatzkes, "Kobe: A Japanese Haven for Jewish Refugees 1940-1941," Japan Forum 3 (1991): 257-273. 
3 See David Goodman and Masanori Miyazawa, Jews in the Japanese Mind (Lanham, MD: Lexington Books, 1995) and Shillony, The Successful Outsiders.

4 On early Japanese interest in Judaism, see: Shillony, The Successful Outsiders; Goodman and Miyazawa, Jews in the Japanese Mind; Benite Ben Dor, The Ten Lost Tribes: A World History (Oxford: Oxford University Press, 2009); and Marvin Tokayer, Ancient History of the Jewish and Japanese Mystery (Tokyo: Sanmondoi Publications, 2009).

Chapter 3: Japanese Images of the Jews: Myths,

\section{Canards and Fears}

1 On McLeod, see his books Korea and the Lost Ten Tribes of Israel (Yokohama, 1879) and Japan and the Lost Tribes of Israel (Nagasaki, 1879).

2 For material on Sakai see Sakai Shogun, Yudaya Minzoku no dai-imbo (Tokyo: Naigai Shobo, 1924). On Sakai and Oyaba see also Shillony, The Successful Outsiders, and Goodman and Miyazawa, Jews in the Japanese Mind.

3 On Eidelberg see Rotem Kowner and Judith Rosenhouse, "Hebrew and Japanese are Not-Related: A Comparative Linguistic Study," in Chelkat Lashon 35 (2004): 43-64.

4 Chuo Koron (Tokyo: June 1905).

5 For the definition of Kokutai see Ben-Ami Shillony, Modern Japan: Culture and History (Tel Aviv: Schocken, 1997), 174-175.

6 On Japan's intervention in Siberia see: David Dallin, The Rise of Russia in Asia (Hamden: Archon Press, 1971); Joseph Ferguson, Japanese-Russian Relations, 1907-2007 (London: Routledge, 2008); John J. Stephen, The Russian Far East: A History (Stanford: Stanford University Press, 1994); James Morley, The Japanese Thrust into Siberia, 1918 (New York: Columbia University Press, 1957); Henry Norton, The Far Eastern Republic of Siberia (London: Allen and Unwin, 1923); and Jonathan Smele, Civil War in Siberia: The Anti-Bolshevik Government of Admiral Kolchak (Cambridge: Cambridge University Press, 1996); N.G. Pereira, White Siberia (Montreal: McGill-Queens University Press.

7 There is a vast literature on the Protocols of the Elders of Zion. See, for example, the entry on themin the Encyclopedia Judaica. See also: Norman Cohn, Warrant for Genocide (London: Eyre and Spottiswoode, 1967); David Goodman, "The Protocols of the Elders of Zion: Aum and Anti-Semitism in Japan, (Jerusalem, Vidal Sassoon International Center for the Study of Anti-Semitism, no. 2, 2005); Jacob Kovalio, The Protocols of Zion in Japan: Yudayaka/Jewish Peril, Propaganda and Debates in the 1920's (New York: Peter Lang, 2009); Rotem Kowner, "The Protocols in a Land without Jews:A Reconsideration," Anti-Semitism International 3-4 (2006): 66-77; ibid, "On Symbolic Anti-Semitism: Motives for the Success of 
the Protocols in Japan and its Consequences," Posen Papers; David Kranzler, “The Japanese Ideology of Anti-Semitism and the Holocaust," in Randolph Braham, ed., Contemporary Views of the Holocaust (Boston: Kluwer-Nijhoff, 1983), 79-107, and Stanley Rosenman, "Japanese Anti-Semitism: Conjuring up Conspiratorial Jews in a Land without Jews," The Journal of Psychology 25 (1997): 2-32.

8 For the circulation of the Protocols in Japan in the 1920's, see Yasue Norihiro, Sekai Kakumei no Rimen (The Seamy Side of the World Revolution) (Tokyo: Niseisha, 1924).

9 For a biography of Konoye, see Oka Yoshitaka, Konoye Fumimaro: A Political Biography (Tokyo: 1983).

10 See Sakuzo Yoshino, "Iwayara sekai-teki himitsu no kessha no Shotai," in Chuo Koron (June 1921): 2-42.

11 For material on Yasue Norihiro, see Avraham Altman, "Controlling the Jews, Manchukuo Style," in Malek Roman, ed., Jews in China, 300-305. See also Yasue Hiro, The Dairen Special Services Agency and the Visionary Jewish State (in Japanese)(Tokyo: 1989).

12 See Inuzaka Kiyoko, Yudaya Mondai to Nihon no Kosaku: Kaigun Inuzuka Likan no Kiroku (The Jewish Question and Japan's Strategy: The Records of the Navy and Inuzuka) (Tokyo: Nihon Kogyo Shinbunsha, 1982).

13 See Shioden Nobutaka, Yudaya shiso oyobi undo (Tokyo: Naigai Shobo, 1941). See also his Kaikoroku (Tokyo: Misuzu Shobo, 1964).

14 On Kitta Ikki, see George Wilson, Radical Nationalist in Japan: Kitta Ikki, 1883-1937 (Cambridge, MA: Harvard University Press, 1969.)

15 For information on Ludwig Reiss, see Shillony, The Successful Outsiders, 131.

16 For material on Kanzo Uchimure and Hasegawa Nizkan, see Shillony, The Successful Outsiders.

Chapter 4: Nazi Antisemitism and its Influence on Japan in the 1920's and 1930's

1 There is a vast literature on Japanese-German relations. See, for example: Kurt Bloch, German Interests and Policies in the Far East (New York: Institute of Pacific Relations, 1940); Carl Boyd, "The Berlin-Tokyo Axis and Japanese Military Initiative," Modern Japanese Studies 15 (1981): 321-345; Herbert Von Dirksen, Moscow, Tokyo, London: Twenty Years of German Foreign Policy (Norman, OK: University of Oklahoma Press, 1952); Hugo Dobson, "The Failure of the Tripartite Pact: Familiarity Breeding Contempt between Japan and Germany," Japan Forum II (1999): 179-190; H.S. Furuya, "Nazi Racism toward the Japanese: Ideology vs. Realpolitik," achrichten der Gesselschaft fur Natur und Volkerkunder Ostasiens 157-158 (1995): 17-75; Ienaga Saburo, 
The Pacific War, 1931-1945 (New York: Pantheon Books, 1978); Frank Ikle, German-Japanese Relations, 1936-1940 (New York: Bookman, 1957; Gerhard Krebs, Japan's Deutschland Politik, 1935-1941 (Hamburg: 1984); Hirama Krug and B. Nagashima, Reluctant Allies: German-Japanese Naval Relations in World War II (Annapolis, MD: Naval Institute Press, 2001); Kudo Akira, Tajima Noburo, and Pauer Erich, eds., Japan and Germany: Two Latecomers to the World Stage, 1890-1945 (Folkestone: Global Oriental Press, 2009); W.G. Malatrich, Samurai and Superman: National Socialist Views of Japan (Bern: Peter Lang, 2005); Bernd Martin, Deutschland und Japan in Zweiten Weltkrieg: Von Angriff auf Pearl Harbor bis zur Deutschen Kapitulation (Gottingen: Musterschmidt Verlag, 1969); ibid, Japan and Germany in the Modern World (New York: Oxford University Press, 1995); Johanna Meskill, Hitler and Japan: The Hollow Alliance (New York: Atherton Press, 1966); James Morley, Deterrent Diplomacy: Japan, Germany and the USSR, 1935-1940 (New York: Columbia University Press, 1976); Ian Nish, Japan's Foreign Policy, 18681945 (London: Routledge, 1977); Ernest Presseissen, Germany and Japan: A Study in Totalitarian Diplomacy, 1933-1941 (The Hague: Nijhoff, 1958); Paul Schroder, The Axis Alliance and Japanese-American Relations (Ithaca, NY: Cornell University Press, 1958); and Paul Wippich, ed., Japan-German Relations, 1895-1945 (London: Routledge, 2006).

2 See David Goodman and Masanori Miyazawa, Jews in the Japanese Mind (Lanham, MD: Lexington Books, 1995).

3 For quotes on Jewish influence in the United States and the Jews' supposed aim of destroying America, see Ben-Ami Shillony, "Hatred of Jews without Jews: Japan’s Anti-Semitic Ideology during World War II," Zion 46 (1981): 125-145.

4 On Alfred Rosenberg see: Robert Cecil, The Myth of the Master Race: Alfred Rosenberg and the Nazi Ideology (New York: Dodd \& Mead, 1972); Albert Chandler, Rosenberg's Nazi Myth (New York: Greenwood Press, 1945); Fritz Nova, Alfred Rosenberg: Nazi Theorist of the Holocaust (New York: Buccaneer Books, 1986); and James Whisher, The Philisophy of Alfred Rosenberg (New York: Noontide Press, 1996).

5 For books on German-Japanese relations, see reference 34.

6 See Marvin Tokayer and Mary Swartz, The Fugu Plan: The Untold Story of the Japanese and the Jews during World War II (New York: Paddington Press, 1979).

7 Some Japanese writers thought that Hitler was a passing fad. See John Fox, “Japanese Reactions to Nazi Germany's Racial Legislation," The Wiener Library Bulletin 23 (1969); H. Furuya, "Nazi Racism Toward the Japanese: Ideology vs. 
Realpolitik," Nachrichten der Gesselschaft for Natrur und Volkerkunde Osasiens 157 (1995): 17-75.

\section{Chapter 5: Japanese Experts on Jews, Judaism, and Zionism}

1 On Yasue and Inuzuka see Yoshia Toshio, "Yudaijin to Tokumukikancho: Yudaya Minzoku wo sukutta Yasue Taisa no shogai (The Jews and the Office of Social Military Forces: The Career of Colonel Yasue, Who Saved the Jewish People)," Bungei Shinju 41 (1963): 156-164; and Inuzuka Kiyoku, Yudaya Mondai to Nihon no Kosaku: Kaigun Inuzuka Kikan no Kiroku (The Jewish Question and Japan's Strategy: The Records of the Navy and Inuzuka) (Tokyo: Nihon Kogyo Shinbunsha, 1982).

2 On the Jewish community in Harbin, see B. Bressler, "Harbin's Jewish Community 1898-1958, Politics, Prosperity and Adversity," in Jonathan Goldstein, ed., The Jews of China, 200-215; Herman Dicker, Wanderers and Settlers in the Far East; Joshua Fogel, "The Japanese and the Jews in Harbin 1898-1930," in Robert Bickers, et al, eds., New Frontiers: Imperialists, New Communities in East Asia, 1892-1953 (Manchester: University of Manchester Press, 2000), 88-108; Hayasaka Takashi, "Shikan no ketsudan: Minshu to Attsu no shogun Huguchi Kiichiro," Bungei Shinju (2010); Teddy Kaufman, The Jews of Harbin Live On in My Heart (Tel Aviv: Association of Former Jewish Residents of China, 2004);. Pan Guang, Jews in China (Beijing: China International Press, 2001); Z. Shickman-Bowman, "The Construction of the Chinese Eastern Railway and the Origins of the Harbin Jewish Community, 1898-1931," in Goldstein, The Jews of China; Irene Eber, Way of the Land: The Jewish Communities of Harbin, Tianjin, and Shanghai, An Introduction (Tel Aviv: Beit Hatfutsot, 1986); R. Malek, ed., From Kaifeng to Shanghai: Jews in China (Sankt Augustin: Monumenta Serica Monograph Series XLVI, 2000); Xu Xin, "Jewish Diaspora in China," Bulletin of the Association of Former Jewish Residents of China 45 (2012): 32-41; and Wei Qu and Shuxiao Li, eds., The Jews of Harbin (Harbin: Social Sciences Documentation Publishing House, 2003).

3 See: Maruyama Naoki, "Japan's Response to the Zionist Movement in the 1920's," Bulletin of the Graduate School of International Relations 2 (1984); Shillony, The Successful Outsiders, 151-163; Goodman and Miyazawa, Jews in the Japanese Mind.

4 Maruyama, "Japan's Response to the Zionist Movement."

5 On the Kadoorie family, see Mavis Meyer, "The Sephardi Jewish Community of Shanghai and the Question of Identity," in Roman Malek, ed., Jews in China, 345-373 and Mavis Meyer, From the Rivers of Babylon to the Whangpoo: 
A Century of Sephardi Life in Shanghai (Lanham MD: University Press of America, 2003).

6 Israel Cohen, The Journal of a Jewish Traveler (London: Bodley Head, 1925).

7 Maruyama.

8 On Japan-Arab ties, see Frank Shulman, "The Nature of Japanese Activity in the Middle East: Japanese Middle Eastern Economic and Political Relations Since World War II," unpublished MA thesis, Ann Arbor, University of Michigan Center for Japanese Studies, 1968.

\section{Chapter 6: Japan and the Jews of Manchuria Beginning in 1931}

1 On Japan and the Jews of Manchuria see: Avraham Altman, "Controlling the Jews, Manchukuo Style," in R. Malek, ed., From Kaifeng to Shanghai, 279317; Jonathan Goldstein, The Jews of China; Gerald Keraney, "Jews Under Japanese Domination, 1939-1945," Shofar 21 (1993): 54-59; Y. Matsusaka, The Making of Modern Machuria, 1904-1932 (Cambridge: Harvard University Press, 2001). Ogata Sadako, Defiance in Manchuria: The Making of Japanese Foreign Policy, 1931-1932 (Berkeley: University of California Press, 1964); Pamela Rotner Sakamoto, Japanese Diplomats and Jewish Refugees: A World War II Dilemma (New York: Praeger, 1998); Yamamuro Shiníchi, Manchuria under Japanese Domination (Philadelphia: University of Pennsylvania Press, 2006); L. Young, Japan's Total Empire: Manchuria and the Culture of Wartime Imperialism (Berkeley: University of California Press, 1998).

2 On Japan's New Order, see Francis C. Jones, Japan's New Order in East Asia: Its Rise and Fall, 1937-1945 (London: Oxford University Press, 1954).

3 On the Kaspe Affair, see D. Ben-Canaan, The Kaspe File: A Case Study of Harbin as an Intersection of Cultural and Ethnical Communities in Conflict (Harbin: Heilongjang People's Publishing House, 2009) and David Bergamini, Japan's Imperial Conspiracy (London: Panther Books, 1971), 562-566.

4 Altman, Controlling the Jews, Manchukuo Style.

5 Kaufman, Teddy, The Jews of Harbin.

6 On the Far East Congress see Altman, Controlling the Jews, Manchukuo Style, and Maruyama Naoki, "Facing a Dilemma: Japan's Jewish Policy in the late 1930's," in Guy Podoler, ed., War and Militarism in Modern Japan: Issues of History and Identity (Folkestone: Global Oriental, 2009), 22-38.

7 On the Birobijan Plan see Tokayer, The Fugu Plan.

8 Arita's response in the Diet quoted in Goodman and Masanori, The Jews in the Japanese Mind.

9 Kaufman, The Jews of Harbin.

10 Xu Xin, "Jewish Diasporas in China." 
Chapter 7: Passports, Entry Visas, and Transit Visas: Japan's policy toward Jewish Refugees (1935-1941)

1 Pamela Sakamoto, Japanese Diplomats and Jewish Refugees.

2 Maruyama Naoki, "Facing a Dilemma."

3 On the Five Ministers Conference see Maruyama.

4 Shillony, The Successful Outsiders, and Goodman and Miyazawa, Jews in the Japanese Mind.

\section{Chapter 8: The Jews of Shanghai under Japanese Rule}

1 There is an extensive literature on the Shanghai Jewish community. It includes: Avraham Altman and Irene Eber, "Flight to Shanghai, 1938-1940: The Larger Setting," Yad Vashem Studies 28 (2000): 42-71; Bernice Archer, The Internment of Western Civilians under the Japanese 1941-1945: A Patchwork of Internment (Hong Kong: Hong Kong University Press, 2008); Bei Gao, Shanghai Sanctuary: Chinese and Japanese Policy Towards European Jewish Refugees in World War II (New York: Oxford University Press, 2013); Irene Eber, Chinese and Jews: Encounters between Cultures (Middlesex, Mitchell Valentine, 2008); Irene Eber, Voices from Shanghai: Jewish Exile in Wartime China (Chicago: Chicago University Press, 2008); Irene Eber, Wartime Shanghai and the Jewish Refugees from Central Europe: Survival, Existence and Identity in a Multi-Ethnic City (Berlin: De Gruyter, 2012); Jacob Edelstein, "The Mir Yeshiva in Shanghai During the Second World War," Kivunim 19 (1983): 127-134; A. Freyesen, Shanghai und fie Politik des Dritten Reiches (Wurzburg: Koningshausen and Neumann, 2000); Violet Gilboa, China and the Jews (Cambridge, MA: Harvard University Press, 1993); Jonathan Goldstein, The Jews of China; Jonathan Goldstein, "Shanghai as a Mosaic and Microcosm of Eurasian Jewish Identities, 1850-1859," Religions and Christianity in Today's China 3 (2013): 18-45; Ernst Heppner, Shanghai Refugee: A Memoir of the World War II Jewish Ghetto (Lincoln: University of Nebraska Press, 1993); His-Huey Liang, The Sino-German Connection (Assen: Van Gorcum, 1978); Steve Hochstadt, Exodus to Shanghai: Stories of Escape from the Third Reich (New York: Palgrave MacMillan, 2012); William Kirby, Germany and Republican China (Stanford: Stanford University Press, 1984); David Kranzler, Japanese, Nazis and Jews: The Jewish Refugees in Shanghai, 1938-1945 (New York: Yeshiva University Press, 1976); Rena Krasno, Strangers Always: A Jewish Family in Wartime Shanghai (Berkeley: Pacific View Press, 1992); Rena Krasno, The Last Glorious Summer 1939: Shanghai-Japan (Hong Kong: Old China Press, 2001); Yecheskel Leitner, Operation Torah Rescue: The Escape of the Mirrer Yeshiva from Wartorn Poland to Shanghai in China (New York: Feldheim, 1987); Leo 
Baeck Institute, Destination Shanghai: Refugees or Stateless Jews (New York: Leo Baeck Institute, 1996); Itamar Livni, “The German Jewish Immigrant Press in Shanghai," in Raoul Findeisen, et al, eds., At Home in Many Worlds (Wiesbaden: Harrasowitz Verlag, 2009), 273-283; Anna Lincoln, Escape to China, 1939-1948 (New York: Maryland Books, 1982); Isabella Martinet, Les Juifs de Shanghai:xix-xx siecles (Paris: Roillat, 2008); Maruyama Naoki, "The Shanghai Zionist Association and the International Politics of the Far East until 1936," in Goldstein, The Jews of China; Maruyama Naoki, Taiheiyo senso to Shanhai no Yudaya nanmin (The Pacific War and the Jewish Refugees in Shangahi) (Tokyo: Hosei Daigaku, 2005); Maisie Meyer, From the Rivers of Babylon; Rana Mitter, na's War with Japan (London: Allen Lane, 2013); Rhoads Murphey, Shanghai: Key to Modern China (Cambridge MA: Harvard University Press, 1953); Pan Guang, The Jews of Shanghai (Shanghai: The Shanghai Pictorial Publishing House, 1995); Pan Guang, The Jews of China (Shanghai: China International Press, 2001); Marcia Ristaino, Port of Last Resort: The Diaspora Communities of Shanghai (Stanford: Stanford University Press, 2001); James Ross, Escape to Shanghai: A Jewish Community in China (New York: The Free Press, 1994); Evelyn Pike Rubin, Ghetto Shanghai (New York: Shengold, 1993); Pamela Sakamoto, Japanese Diplomats and Jewish Refugees; Maho Sekine, Nihon Senryoko no Shanhai Yudayajin Getto (The Shanghai Ghetto under the Japanese Occupation) (Kyoto: Showado, 2010); Marvin Tokayerand Mary Swartz, The Fugu Plan; Cheng Ziaohong, Noriko Sawadi, and Judy Meschel, TheLast Refuge: The Story of the Jewish Refugees in Shanghai (Teaneck, NJ: Ergo Media, 2004); Ephraim Zuroff, "The Issue of Entry Permits to Shanghai in 1941: The Problem of Preference in Saving Lives," Yad Vashem Studies 13 (1973): 237-256; And Ephraim Zuroff, The Response of Orthodox Jewry in the United States to the Holocaust (New York: Ktav, 2000).

2 On Yozef Meisinger, see Heinz Maul, Why Has Japan Not Persecuted the Jews (Tokyo, Fuyo Shobo Shuppan, 2004).

3 See Yosef Tekoah, "Memoirs," in Jonathan Goldstein, ed., The Jews of China.

4 On antisemitism in China, see Meron Medzini, "China, the Holocaust, and the Birth of Israel," Israel Journal of Foreign Affairs 7 (2013): 135-145.

5 Donald McKale, “The Nazi Party in the Far East," The Journal of Contemporary History 12 (1997): 291-311. See also Donald McKale, The Swastika Outside Germany (Kent: Kent State University Press, 1997).

Chapter 9: Jews in the Japanese-Occupied Territories during the War Years

1 For the March 1942 decisions, see Kranzler, Japanese, Nazis and Jews. 
2 On the Singapore Jewish community in war and peace, see: Nathan Aluph, Singapore Jewry on the Threshold of Paradise (Tel Aviv: Golan, 1996); Joan Bieder and Eileen Lau, The Jews of Singapore (Singapore: Suntree Media, 2007); Justin and Robin Corfield, eds. Encycloaedia of Singapore (Singapore: Scarecrow Press, 2006); Peter Duus and R. Myers, The Japanese Wartime Empire (Princeton: Princeton University Press, 1996); Nathan Eze, The History of the Jews of Singapore, 1830-1945 (Singapore: Herbilu, 1986); Reuven Kashani, Jewish Communities in the Far East (Jerusalem: 1982); R. Myers and M. Peattie, eds., The Japanese Colonial Empire, 1895-1945 (Princeton: Princeton University Press, 1984); Gabriel Weiman and Baruch Navo, The Singapore Riddle (Jerusalem: Tsivonim, 2001); and Moshe Yegar, "History of the Jewish Community of Singapore," Gesher 1 (1974): 50-65.

3 On the Jews of Burma: see Ida Cowan, The Jews in Remote Parts of the World (Englewood Cliffs, NJ: Prentice Hall, 1971); Ruth Fredman-Cernea, Almost Englishmen: Baghdadi Jews in British Burma (Lanham, MD: Lexington Books, 2000); Jonathan Goldstein, "Memory, Place and Displacement in the Formation of Jewish Identity in Rangoon and Surabaya," in David Cesarani, Tony Kushner, and Milton Shain, eds., Zakor v'Makor: Place and Displacement in Jewish History and Memory (London, Valentine Mitchell, 2009), 88-98; Mavis Hyman, The Jews of the Raj (London: Hyman Publishers, 1997); and Gerald Keraney, "Jews Under Japanese Domination, 1939-1945," Shofar (1993): 54-59.

4 For the fate of the Jews in the Philippines during the war, see: Frank Ephraim, Escape to Manila: From Nazi Tyranny to Japanese Terror (Urbana: University of Illinois Press, 2003); Lewis Gleeck, History of the Jewish Community in Manila, n.d.; Jonathan Goldstein, “1942: A Year of Survival for Philippine Jews at the Edge of the Diaspora," Australian Journal of Jewish Studies (2014): 66-84; Jonathan Goldstein, "Secular, Jewish, Filipino and Zionistic: From Marranos to 'Bagel Boys," in Ber Boris Kotlerman, ed., Mizrekh: Jewish Studies in the Far East Vol. 2 (Frankfurt: Peter Lang, 2010); Jonathan Goldstein, "Shaping Zionist Identity: The Jews of Manila as a Case Study," Israel Affairs 15 (2009): 296-304; and Dean Kotlowsky, "Breaching the Paper Walls: Paul McNutt and Jewish Refugees to the Philippines, 1938-1939," Diplomatic History 23 (2009): 865-896.

5 On the fate of the Jews in Indonesia, see: Henry Benda, J. Irikura, and K. Kishi, Japanese Military Administration in Indonesia: Selected Documents (New Haven: Yale University Press, 1965); Duus, Myers, and Peattie, eds., The Japanese Wartime Empire; J. Hadler, "Translations of Anti-Semitism: Jews, the Chinese and Violence in Colonial and Post Colonial Indonesia," Indonesia and Malay World 32 (2004):: 291-313; Jonathan Goldstein, "Memory, Place 
and Displacement in the Formation of Jewish Identity in Rangoon and Surabaya," in David Cesarani, Tony Kushner, and Milton Shain, eds., Zakor v'Makor, 88-98; L. de Jong, The Collpase of a Colonial Society: The Dutch in Indonesia During the Second World War (Leiden, KITLV Press, 2002); and Rotem Kowner, Rotem, "An Obscure History: The Prewar History of the Jews in Indonesia," in Indonesia Today 104 (2011). The key articles on the fate of Indonesia's Jews under the Japanese are Rotem Kowner, "The Japanese Internment of Jews in Wartime Indonesia and its Causes," Indonesia and the Malay World 38 (2010): 349-371 and Rotem Kowner, "End of a Colonial Community: Indonesian Jewry in World War II," Zmanin 127 (2014): 60-71. See also: Ayelet Klemperer-Cooperman, "Only God will Protect Me: Jews in Japanese Concentration Camps in Indonesia," Zmanim 127 (2014): 72-79; Chaim Nussbaum, Chaplain of the River Kwai: Story of a Prisoner of War (New York: Shapolsky, 1988); J. Presser, The Destruction of Dutch Jews (New York: Dutton, 1968); and Merle Ricklefs, A History of Modern Indonesia since c. 1200 (Stanford: Stanford University Press, 2008).

6 On the Hong Kong community, see Stanley Jackson, The Sassoons. See also: Tony Banham, We Shall Suffer There: Hong Kong's Defenders Imprisoned, 19421945 (Hong Kong: Hong Kong University Press, 2009); Dennis Leventhal, The Jewish Community of Hong Kong: An Introdcution (Hong Kong: Jewish Historical Society of Hong Kong, rev. ed. 1988); and Dennis and Mary Leventhal, eds., Faces of the Jewish Experience in China (Hong Kong, Hong Kong Jewish Chronicle, 1990).

7 For the history of the Jews in French Indo-China, see: Pierre Birnbaum, The Jews of the Republic: A Political History of the State of the Jews in France from Gambetta to Vichy (Stanford: Stanford University Press, 1996); The Universal Jewish Encyclopaedia (New York: The Universal Jewish Encyclopedia Inc., 1942); and Eric Jennings, Vichy in the Tropics: Petain's National Revolution in Madagascar, Guadeloupe and Indo-China, 1940-1944 (Stanford: Stanford University Press, 2004).

8 On the Jews of Penang, see Eliyahu Birnbaum, Jews of the World (Tel Aviv: Makor Rishon, 2010), 222-226.

9 The main source for the Thailand Jewish community is Ruth Gerson and Stephen Mallinger, Jews of Thaland (Bangkok: River Books, 2011). See also Yehuda Assia, Bridges in My Life (Tel Aviv: Maariv, 2005).

10 On the absorption of the Jews from South East Asia into the native Jewish communities of India, see Joan G. Roland, The Jewish Communities of India (New Brunswick, NJ: Transaction Publishers, 1989) and Esmond David Ezra, Turning Back the Pages: A Chronicle of Calcutta Jewry (London: 1986). 


\section{Chapter 10: A Japanese Righteous Gentile: The Sugihara Case}

1 There exists a vast literature on Sugihara. Some of the more important works are: Ann Akabori Hoshinko, The Gift: A Biographical Account of Japanese Diplomat Sugihara (Sacramento: Edu-Comm Plus, 2005); Akira Kitade, "How the Sugihara Survivors reached Japan," in Kokusai Kankou Jouhon (International Tourism Center of Japan) (Tokyo: June 2011); J.W.M. Chapman, "The Polish Connection: Japan, Poland and the Axis Alliance," in Gordon Daniels and Peter Lowe, eds., Proceedings of the British Association for Japanese Studies (Sheffield: University of Sheffield Center for Japanese Studies, 1977), 57-78; EvaFogelman, Conscience and Courage: Rescuers of Jews During the Holocaaust (New York: 1994); Kubata Taro, "Sugihara Chiune, dei Juden retter aus Japan," Zeitschrift fur Geschischts Wissenschaft 55 (2007); 645-660; Yechezkel Leitner, Operation Orah Rescue; and Hillel Levine, In Search of Sugihara: The Elusive Japanese Diplomat Who Risked his Life to Rescue 10,000 Jews from the Holocaust (New York: The Free Press, 1996); Eva Palasz-Rutkowska, "Polish-Japanese Secret Cooperation During World War II: Sugihara Chiune and Polish Intelligence," Japan Forum 2 (1995); Mizuuchi Ryuta, "Sugihara's Visas: Unknown Facts and Hidden Memories," presented in Jerusalem, The Hebrew University, April 13, 1987; Sugihara Yukiko, Rokusen min no Inochi no visa (Visas for 6000 Lives: One Japanese Diplomat Aided the Jews) (Tokyo: Asahi Sonorama, 1990, and South San Francisco: EduComm Plus, 1995); Sugihara Seishiro, Chiune Sugihara and Japan's Foreign Ministry (Lanham, MD: University Press of America, 2001); Tainuchi Yutaka, The Miracle Visas (Jerusalem: Geffen, 2001); Zorach Warhaftig, Refugees and Survivors: Rescue Efforts During the Holocaust (Jerusalem: Yad Vashem, 1988); Rescue Attempts During the Holocaust (Jerusalem: Yad Vashem, 1977); and Ephraim Zuroff, "The Rescue of Polish Yeshiva Students Via the Far East During the Holocaust," in From Generation to Generation, 49-76.

\section{Chapter 11: The Japanese Policy toward the Jews in} Japan's Home Islands

1 On Jewish musicians in Tokyo during the war, see Luciana Galliano, "Manfred Gurlitt and the Japanese Operatic Scene 1939-1972," Japan Review 18 (2006): 215-248.

2 Shillony, The Successful Outsiders, 178-189.

3 On popular antisemitism in Japan after the war, see: Jennifer Golub, “The Japanese Attitude Towards Jews," American Jewish Committee, Los Angeles, 1992; David Goodman, and Masanori Miyazawa, Jews in the Japanese Mind;David Goodman, "Anti-Semitism in Japan: History and Current 
Implications," in Frank Dikoter, ed., The Construction of Racial Identities in China and Japan (London, 1977); David Goodman, "The Protocols of the Elders of Zion: Aum and Anti-Semitism in Japan," Jerusalem, Vidal Sassoon Center for the Study of Anti-Semitism, no. 2 (2005); Ikeda Afikumi, "Japan's Perception of Jews and Israel," Forum 59 (1986): 73-84; Rotem Kowner, "On Ignorance, Respect and Suspicion: Current Japanese Attitude towards Jews," Jerusalem, Vidal Sassoon Center for the Study of anti-Semitism, 1997; Rotem Kowner, "Tokyo Recognizes Auschwitz: The Rise and Fall of Holocaust Denial in Japan 1989-1999," Journal of Genocide Studies 3 (2001): 257-272; Rotem Kowner, "On Symbolic Anti-Semitism: Motives for the Success of the Protocols in Japan and its Consequences," Posen Papers in Contemporary anti-Semitism, Jerusalem; Stanley Rosenman, "Japanese Anti-Semitism: Conjuring up Conspiratorial Jews in a Land without Jews," The Journal of Psychology 25 (1997): 2-32; Zvi Werblowsky, "The Japanese and the Jews," Jewish Journal of Sociology 20 (1978): 75-81; and Ben-Ami Shillony, "Japanese Views of Jews and Judaism" (Jerusalem, Harriman Center for Contemporary Judaism, 1993).

\section{Chapter 12: "The Jewish Question" in}

Japanese-German relations, 1936-1945

1 On the Jewish issue in Japan-German relations, see: Gerhard Krebs, "The Jewish Problem in Japanese-German Relations, 1933-1945," in Bruce E. Reynolds, ed., Japan in the Fascist Era (New York: Palgrave MacMillan, 2004), 107-132; and Francoise Kreissler, “Japan's Judenpolitik, 1931-1945," in Gerhard Krebs, and Bernd Martin, eds., Formierung und Fall der Achse berlin-Tokyo (Munich: Ludicum, 1984), 187-210.

Chapter 13: The Japanese, the Holocaust of European Jewry, and Israel

1 See: Ian Buruma, The Wages of Guilt: Memories of War in Germany and Japan (New York: Farrar, Strauss, and Giroux, 1994); Goodman and Miyazawa, Jews in the Japanese Mind; Thomas R. Havens, Valley of Darkness: The Japanese People and World War II (New York: Norton, 1978); Rotem Kowner, “Tokyo Recognizes Auschwitz”; Tetsu Kohno, “The Jewsish Question in Japan,” Jewish Journal, of Sociology 29 (1987): 37-54; TetsuKohno, "Debates on the Jewish Question in Japan," Bulletin of the Faculty of Liberal Arts 46 (1983), 1-33; C. Rittner, ed., Anne Frank in the World: Essays and Reflections (Armonk, NY: Sharpe, 1998); Philip Seaton, Japan's Contested War Memoirs (London: Routledge, 2007); Shillony, The Successful Outsiders; Shillony, "Auschwitz and 
Hiroshima: What Can the Jews and Japanese Do for World Peace," Bulletin of the International House 27 (2007): 1-18; Shillony, "The Flourishing Demon: Japan in the Role of the Jews," in Robert Wistrich, ed., Demonizing the Other: Anti-Semitism, Racism and Xenophobia (Amsterdam: Harwood Academic, 1999); and Toyama Kiyhiko, War and Responsdibility in Japan (London, 2008).

2 Shulman.

3 On Holocaust denial in Japan, see Kowner, "Japan Recognizes Auschwitz," and Yashiko Nozaki, War Memory, Nationalism and Education in Postwar Japan (London, 2008).

4 On Israel-Japan relations, see the following works in Hebrew: Elyashiv BenHorin, "Basic Outline of Israel's Position in Asia," New Middle East 4 (1957): 245-252; Yosef Haddas, "The Peace Process: The Multilateral Track," in Moshe Yegar, et al, eds., The Foreign Ministy: The First Fifty Years (Jerusalem: Keter, 2002), 211-226; Moshe Yegar, The Long Journey to Asia:A Chapter in the History of Israeli Diplomacy (Haifa: Haifa University Press, 2004); Yaacov Cohen, "Israel-Japan: 50 Years of Relationships, Past and Future," in Moshe Yegar, et al, eds., The Foreign Ministry: The First Fifty Years, 550-564; Meron Medzini, "Asia in Israel's Foreign Policy," State and Government 1 (1971): 110-121; BenAmi Shillony, "Japan and Israel: Continuing and Developing Relations," in Benjamin Neuberger, ed., Selected Issues in Israel's Foreign Relations (Tel Aviv: Open University, 1992), 441-452; Ben-Ami Shillony, "Japan and Israel: The Relationship that Withstood Pressure," Middle East Review 18 (1985); Moshe Sharett, A Voyage in Asia (Tel Aviv: Davar, 1957), and Raquel Shaoul, "Japan and Israel: An Evaluation of Relationship Building in the Context of Japan's Middle East Policy," in Ephraim Karsh, ed., Israel: The First Hundred Years (London: Cass, 2004).

5 Jonathan Goldstein, "Japan and Israel: From Erratic Contacts to Recognition to Boycott to Normalization," in Colin Schindler, ed., Israel and the World Powers (London: IB Tauris, 2013), 234-283. 